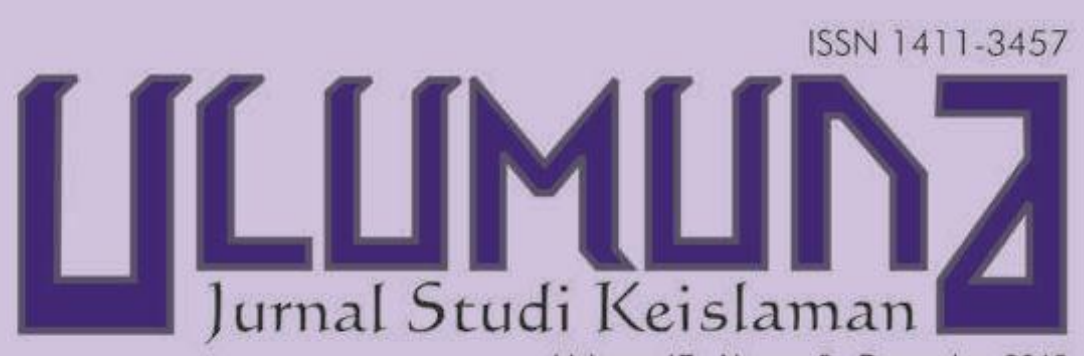

Volume 17· Nomor 2 - Desember 2013

TERAKREDITASI [3, SK Dirjen Dik: Kenmikind Nomor: 56 DIKTIKep 2012. Targgal 24 junt 2012

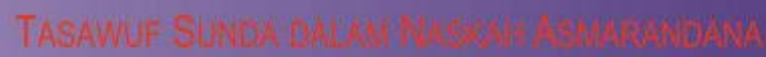
$767(6)$

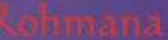

(s):

DALAM TRADISI KEAGM

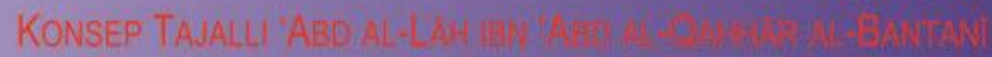

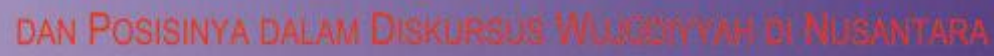

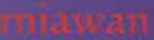

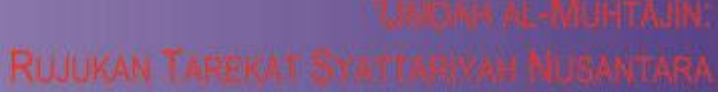

manherit

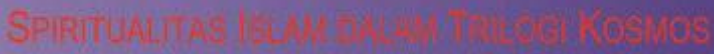

1) thits

YOWMAN:

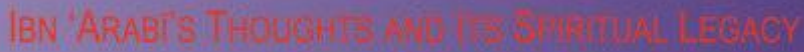

3ेputra

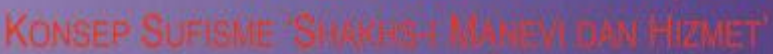

GUIEN

(umayi

Acoxuma

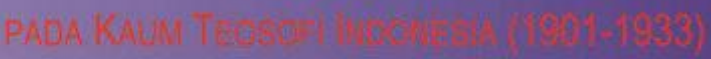

Babei

BASAWUF

Tanany

upinkat 


\section{DAFTAR ISI}

\section{Pedoman Transliterasi}

\section{1-258 • Jajang A Rohmana}

"Tasawuf Sunda dalam Naskah Asmarandana

Ngagurit Kaburu Burit (OR. 7876)”

259-274 • Mashadi

"Konteks dan Corak Mistisisme Islam

dalam Tradisi Keagamaan Masyarakat Gorontalo"

275-302 • Ade Fakih Kurniawan

"Konsep Tajalli 'Abd al-Lāh ibn 'Abd al-Qahhār

al-Bantanī dan Posisinya dalam Diskursus

Wujūdiyyah di Nusantara"

303-322 • Damanhuri

“Umdah al-Muhtàjīin:

Rujukan Tarekat Syattariyah Nusantara"

\section{3-346 • Munawir Haris}

"Spiritualitas Islam dalam Trilogi Kosmos"

347-358 - Hans Abdiel Harmakaputra

"Becoming a Perfect Human:

Ibn 'Arabî's Thoughts and Its Spiritual Legacy"

359-386 • Sulaiman Al-Kumayi

"Konsep Sufisme 'Shakhs-i Manevi dan Hizmet'

Muhammad Fethullah Gülen"

387-420 • Media Zainul Bahri

"Gagasan Pluralisme Agama

pada Kaum Teosofi Indonesia (1901-1933)"

421-440 • Lalu Supriadi

"Studi Komparatif Pemikiran Tasawuf

al-Ghazali dan Ibn Taimiyah"

\section{LAMPIRAN-LAMPIRAN}




\section{PEDOMAN TRANSLITERASI}

\begin{tabular}{|c|c|c|c|c|c|c|}
\hline 1 & $=$ & $\mathbf{a}$ & & $\dot{\varepsilon}$ & $=$ & $\mathrm{g}$ \\
\hline ب & $=$ & b & & ف & $=$ & f \\
\hline$ت$ & $=$ & $\mathbf{t}$ & & ق & $=$ & $q$ \\
\hline$\dot{H}$ & $=$ & th & & ك & $=$ & $\mathbf{k}$ \\
\hline ج & $=$ & $\mathbf{j}$ & & J & $=$ & 1 \\
\hline$\tau$ & $=$ & ḥ & & s & $=$ & $\mathrm{m}$ \\
\hline$\dot{\tau}$ & $=$ & $\mathbf{k h}$ & & $\dot{ن}$ & $=$ & $\mathbf{n}$ \\
\hline$د$ & $=$ & d & & 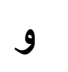 & $=$ & $\mathbf{w}$ \\
\hline$\dot{j}$ & $=$ & dh & & ○ & $=$ & $\mathbf{h}$ \\
\hline$\jmath$ & $=$ & $\mathbf{r}$ & & $\varepsilon$ & $=$ & , \\
\hline j & $=$ & $\mathbf{z}$ & & ي & $=$ & $\mathbf{y}$ \\
\hline س س & $=$ & s & & & & \\
\hline 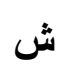 & $=$ & sh & \multicolumn{4}{|c|}{ Untuk Madd dan Diftong } \\
\hline ص - ص & $=$ & ș & i & $=$ & \multicolumn{2}{|c|}{$\bar{a}$ (a panjang) } \\
\hline ض ض & $=$ & d & إي & $=$ & \multicolumn{2}{|c|}{$\overline{1}$ (i panjang) } \\
\hline b & $=$ & $t$ & أو & $=$ & \multicolumn{2}{|c|}{ ù (u panjang) } \\
\hline ظ & $=$ & z & او & $=$ & \multicolumn{2}{|c|}{ aw } \\
\hline$\varepsilon$ & $=$ & ' & أي & $=$ & \multicolumn{2}{|l|}{ ay } \\
\hline
\end{tabular}

Contoh penulisan dengan transliterasi:

(a'üdhu bi al-Lāh min al-shaytān al-rajim); اعوذ بالله من الشيطان الرجيم

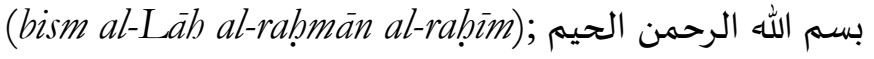

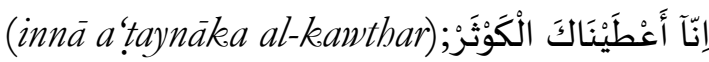

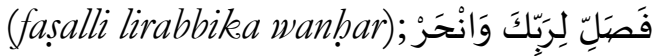

(șabāḥ al-khayr). صبباح الخير 


\title{
SPIRITUALITAS ISLAM DALAM TRILOGI KOSMOS
}

\author{
Munawir Haris \\ (STAIN Sorong Papua Barat \\ Email: irfani.fanani@gmail.com)
}

Abstract: Human beings are mysterious. Although various studies about humans have been conducted, they fail to totally comprehend them. Therefore, studies about humans are always interesting topics, especially if they attempt to reveal non-physical aspects of humans. One way to look at this neglected aspect is to study spiritual dimensions of humans. Base on their explorations to the Qur'an and hadith, Muslim scholars propose a theory of three cosmos: macrocosmos, microcosmos and metacosmos. Macrocosmos represents the Universe. Microcosmos is human beings and metacosmos is concerned with Allah. These are three cosmologies that Muslims have to find from the scriptural texts so they can understand the central role of human beings in preserving balanced relationships among these three worlds. The Qur'an, for example, gives allegories and signs that Muslims must explore their deep meanings to gain wisdom and get closer to the Creator.

Abstrak: Ada banyak dimensi misteri dalam diri manusia. Meski banyak kajian atas manusia oleh para sarjana dan filsuf, namun studistudi mereka gagal memahami keseluruban dimensi tersebut. Oleh karena itu, studi tentang manusia selalu menarik, terutama jika dikaitkan dengan sisi non-fisiknya. Salah satu caranya adalah dengan melakukan kajian spiritualitas manusia. Dengan mendasarkan pada al-Qur'an dan hadis, para sarjana kosmolog Muslim menawarkan konsep tiga dunia; makrokomos, mikrokosmos dan metakosmos. Makrokosmos adalah dunia atau alam raya. Mikrokosmos adalah manusia sedangkan metakosmos berkaitan dengan Allah. Orang-orang Islam kemudian mengeksplorasi rahasia-rahasia di balik al-Qur'an dan hadis untuk mendapatkan makna mengenai peran utama mereka dalam dunia kosmos tersebut dan dalam rangka mengetahui tugas mereka menjaga bubungan antarkosmos. Usaha ini diyakani mampu mengantarkan manusia menjadi bijak dan akan dekat kepada Allah.

Keywords: kosmologi, analogi, manusia, spiritual, jalāliyyah, jamāliyyah. 
SECARA komprehensif, hakekat manusia telah banyak menyita perhatian banyak kalangan. Dari kalangan ilmuan, filsuf, sosiolog, maupun para agamawan. Namun upaya tersebut gagal. Manusia hanya mampu menyingkap hakekat dirinya pada batas instrumen, dan bukan substansi. Karenanya, kajian tentang manusia selalu menarik, tercermin pada disiplin ilmu yang berkembang, baik ilmu murni maupun terapan. Daya tarik pembicaraan tentang manusia, antara lain karena pengetahuan tentang makhluk ini, belum mencapai kemajuan seperti yang telah dicapai dalam bidang ilmu pengetahuan lainnya. Pertanyaan tentang manusia, pada hakekatnya hingga saat ini masih tanpa jawaban pasti. ${ }^{1}$

Sulitnya mengungkap substansi manusia disadari oleh Alexis Carrel. Carrel menyebut manusia sebagai makhluk misterius yang unik yang tak mampu ditelusuri secara keseluruhan. ${ }^{2}$ Ketidakmampuan manusia dalam menelusuri substansi dirinya secara utuh, disebabkan karena keterbatasan pengetahuan manusia. Hal ini menurut pakar tafsir Indonesia, M. Qurasy Shihab, disebabkan tiga faktor, yaitu pertama, dalam sejarah kehidupannya, manusia lebih tertarik melakukan penyelidikan tentang alam materi, dibanding pada hal-hal yang bersifat immaterial; kedua, keterbatasan akal manusia yang hanya mampu memikirkan hal-hal yang bersifat instrumental ketimbang hal-hal yang substansial dan kompleks; ketiga, kompleksitas dan uniknya masalah manusia. ${ }^{3}$

${ }^{1}$ Terdapat beberapa terma yang dipergunakan dalam memahami manusia di dalam al-Qur'an. Beberapa istilah itu terutama al-Bashar, al-Insān, al-Nās dan Bani Adam yang cukup banyak istilah ini digunakan oleh al-Qur'an dalam relasi dengan manusia. Meskipun sesungguhnya terdapat beberapa istilah lain seperti 'Abd al-Läh, Khalifah al-Läh, Ulu al-Bäb dan sebagainya. Pemahaman Quraish Shihab bahwa terma manusia dalam al-Qur'an dinyatakan ada tiga, yaitu: pertama, menggunakan kata yang terdiri dari konsep alif, nūn dan sin semacam insān, ins, nās atau unās. Kedua, menggunakan kata bashar. Ketiga, menggunakan kata Bani Adam dan dhuriàt Adam. Lihat, M. Quraish Shihab, Wawasan al-Qur'an: Tafsir Maudhu'i Atas Pelbagai Persoalan Umat (Bandung: Mizan, 1998), 278.

2Alexis Carrel, Misteri Manusia, ter. (Bandung: Remaja Karya, 1987), 3042.

3Shihab, Wawasan ..., 227-8. 
Di satu sisi, agama dan ilmu pengetahuan dianggap dua entitas yang berbeda dan terpisah. Dalam pandangan dunia, agama bersifat apriori yang bertitik tolak dari sebuah keyakinan untuk sampai kepada kesimpulan yang sejalan dengan keyakinannya yang bersifat absolut. Sedangkan ilmu pengetahuan, bertitik tolak dari sebuah keraguan dan kesimpulan-kesimpulannya bersifat tentatif dan verifiabel. Dengan demikian, menurut mereka, Islam sebagai sebuah agama tidak memiliki perspektif ilmiah mengenai kehidupan, termasuk tidak memiliki perspektif tentang kosmologi yang keduanya merupakan ilmu pengetahuan (sains). Mereka tampaknya tidak akrab dengan sumber-sumber ajaran Islam, al-Qur'an dan alHadis, serta khazanah pemikiran Islam, sehingga dengan tanpa beban meremehkan Islam dalam persoalan-persoalan ilmu pengetahuan.

Al-Qur'an mengungkapkan pandangan dunia (world view) yang tidak semata-mata menekankan dunia fisik, melainkan dunia spiritual. Para ulama melihat alam semesta tidak terutama pada alam itu sendiri, tetapi pada hubungan-hubungan analogis dan alegorisnya dalam keseluruhan sistem yang mengaturnya. Kosmolog muslim membuat teoretisasi yang membedakan dalam pandangan dunia Islam adanya tiga realitas yaitu: makro kosmos, mikro kosmos, dan meta kosmos. Makro kosmos adalah alam semesta pada umumnya, mikro kosmos adalah manusia, dan meta kosmos adalah Allah. Jika kedua alam (makro dan mikro) itu diciptakan oleh Allah apakah mungkin kedua alam itu tidak saling berhubungan, atau keduanya terpisah dari Sang Pencipta. Orang-orang suci dari kalangan muslim seringkali mencoba menemukan misteri-misteri yang tersembunyi di balik teks-teks al-Qur'an dan hadis-hadis. Mereka mencoba untuk menemukan makna serta peran sentral manusia dalam rangkaian hubungan tersebut. Al-Qur'an menekankan berbagai fenomena alam tersebut sebagai tanda-tanda Allah yang harus dicermati dan diambil pelajaran oleh manusia, sehingga mendatangkan hikmah bagi kehidupan manusia. Pemikiran mereka tidak pernah jauh dari keinginan mencari jejak-jejak Sang Pencipta untuk menemukan cara yang paling bijak untuk mendekatkan diri kepada-Nya. 
Simbol kisah penciptaan dan kejatuhan Adam merupakan sebuah alegori yang menyimpan berbagai misteri yang patut direnungkan. Sekurang-kurangnya untuk dapat mengambil manfaat bagi peningkatan pemahaman terhadap realitas kehidupan manusia yang unik serta untuk memahami hubunganhubungan kosmologis dan psikologis antara manusia dan kosmos, serta hubungan keduanya dengan Sang Pencipta.

Tulisan ini membahas berturut-turut konsepsi mengenai dunia spiritual Islam, esensi manusia dalam hubungannya dengan alam semesta dan Tuhan, serta membangun spiritualitas sebagai strategi menjalankan peran sentral manusia di dalam kosmos.

\section{Spiritualitas Islam}

Para kosmolog Muslim mencari petunjuk al-Qur'an dan alHadis untuk dapat memahami korespondensi-korespondensi dan analogi-analogi kualitatif tiga realitas kosmologis: alam semesta (makrokosmos), manusia (mikrokosmos), dan Allah (metakosmos). Mereka tertarik kepada berbagai perumpamaan dan keserupaan-keserupaan dalam sumber-sumber Islam. Mereka ingin menemukan berbagai macam hubungan pada berbagai tataran dan aras kualitatif. Metodologi hermeneutikesoteris mereka gunakan untuk menguak berbagai perumpamaan dan keserupaan dalam Kitab Suci. ${ }^{4}$ Dalam hal ini Sachiko Murata menjelaskan sebagai berikut:

Yang berkaitan erat dengan tipe pemikiran analogis dalam astrologi adalah ta'wil atau interpretasi esoteris atas al-Qur'an. Ini banyak dilakukan oleh para sufi dan juga otoritas-otoritas Syiah tertentu. Seringkali tujuan ta'wil menunjukkan bagaimana ayat-ayat al-Qur'an berbicara tentang kosmos, atau kisah-kisah Nabi, memiliki pengertian lain sesuai dengan tataran dan arah serta situasi batiniah individu manusia. Mikro kosmos sesuai dengan makro kosmos. Pada tataran dan aras ini, al-Qur'an melukiskan drama jiwa manusia dalam hubungannya dengan Allah. ${ }^{5}$

${ }^{4}$ Sachiko Murata, The Tao of Islam: Kitab Rujukan tentang Relasi Gender dalam Kosmologi dan Teologi Islam, ter. Rahmani Astuti dan M.S. Nasrullah (Bandung: Mizan, 1998), 300.

${ }^{5}$ Murata, The Tao..., 37. Di tempat lain, Murata mengemukakan bahwa model penafsiran al-Qur'an yang dikenal dengan ta'wil (hermeneutika 
Al-Qur'an berulang kali menegaskan bahwa segala sesuatu adalah tanda-tanda (al-ayah) Allah dalam artian bahwa segala sesuatu menggambarkan hakekat dan realitas Allah. 6 Akibatnya, banyak pemikir Muslim, khususnya para ahli kosmologi, melihat segala sesuatu di alam semesta sebagai refleksi dari nama-nama dan sifat-sifat Ilahi. Nama-nama dan sifat-sifat ini menggambarkan berbagai kualitas, seperti keagungan, keindahan, kehidupan, pengetahuan, dan seterusnya. Oleh karena itu, dimensi kualitatif segala sesuatu menjadi sangat menarik perhatian.

Prinsip segala sesuatu selain Allah adalah tanda-tanda Allah, sebagaimana diungkapkan oleh al-Qur'an. Diungkapkan pula dengan cara lain dalam sebuah hadis Qudsi yang sangat populer di kalangan sufi dan dijadikan basis konseptualnya dalam memandang hubungan-hubungan kosmologis. Hadis Qudsi itu berbunyi:

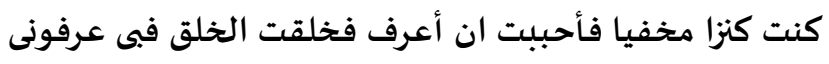

Artinya: Aku pada mulanya adalah harta yang tersembunyi, kemudian Aku ingin dikenal, maka Kuciptakanlah makhluk dan melalui Aku mereka pun kenal padaKu. ${ }^{7}$

Hadis tersebut jelas menunjukkan bahwa dunia, atau alam semesta, atau ciptaan (makhluk) merupakan lokus di mana khazanah tersembunyi diketahui oleh makhluk. Sebaliknya, ciptaan-ciptaan Allah atau alam semesta itulah yang memberitahukan adanya khazanah tersembunyi, yaitu Allah. Proses pengenalan diri Allah kepada makhluk dan melalui

esoteris) bergantung pada analogi-analogi kualitatif di antara segala sesuatu, khususnya antara mikrokosmos dan makrokosmos. Lihat, Murata, The Tao..., 53.

${ }^{6}$ Kata al-āyah dengan berbagai variasinya terulang sebanyak 288 kali di dalam al-Qur'an.

${ }^{7}$ Hadis yang dikenal dengan hadis "Khazanah Tersembunyi" ini dikutip misalnya oleh Harun Nasution, Falsafat dan Mistisime dalam Islam (Jakarta: Bulan Bintang, 1999), 58. Lihat juga Nurcholish Madjid, Simbol dan Simbolisme Keagamaan Populer, serta Pemaknaannya dalam Perkembangan SosialPolitik Nasional Kontemporer, Makalah Pidato Pengukuhan Jabatan Ahli Peneliti Utama (Jakarta: Puslitbang Kemasyarakatan dan Kebudayaan, Lembaga Ilmu Pengetahuan Indonesia [PMB-LIPI], 30 Agustus 1999), 5. 
makhluk ini disebut-sebut oleh banyak ahli kosmologi Islam dengan istilah al-zabir (manifestasi) dan tajalli (pengungkapan diri) Allah, sekaligus untuk menjelaskan hubungan alam semesta dengan Allah.

Alam semesta dalam eksistensi dan fungsinya sebagai cerminan Allah, maka berarti mencerminkan seluruh nama dan sifat-sifat Allah. Sifat sifat Allah dapat dibedakan menjadi dua kategori, yaitu sifat-sifat Jaläliyyah (keagungan) dan Jamäliyyah (keindahan). Sifat Jalaliyyah adalah sifat-sifat keagungan dan kekerasan; sementara sifat Jamäliyyah adalah sifat-sifat keindahan dan kelembutan).

Kendati pun secara keseluruhan alam semesta mencerminkan Allah atau sebagai tanda-tanda Allah, namun setiap makhluk secara sendiri-sendiri mencerminkan salah satu sisi dari dua kategori sifat-sifat Allah. Manusia berbeda dengan makhluk-makhluk lain yang mencerminkan kedua sisi sifat-sifat Allah. Inilah yang disimbolkan dengan dua tangan Allah yang diungkapkan dalam Qs. Shad (38):75: yang artinya: "Allah berfirman: 'Hai iblis, apakah yang menghalangimu untuk sujud kepada apa yang telah Aku ciptakan dengan kedua tanganKu. Apakah kamu menyombongkan diri ataukah kamu (merasa) termasuk orang-orang yang (lebih) tinggi?". Dalam hadis disebutkan juga bahwa Adam (manusia) diciptakan berdasarkan surah (bentuk) Allah. Dengan demikian, hanya manusialah yang mewakili gambaran dan citra lengkap Realitas Ilahi. Sementara, segala sesuatu lainnya memberikan gambaran dan citra tidak sempurna. ${ }^{8}$

Hampir seluruh kosmolog Muslim memanfaatkan ihwal tanda-tanda Allah ini sebagai basis pemikirannya dalam rangka menemukan hubungan-hubungan misterius yang terjalin antara manusia, kosmos, dan Sang Pencipta. Salah satu di antara mereka adalah Ikhwān al-Ṣafa. Ikhwān al-Ṣafa, mengungkapkan korespondensi dan similaritas manusia dengan alam semesta dan

${ }^{8}$ Dibandingkan dengan manusia, makhluk lain, diciptakan dengan satu sisi dari nama, sifatnya. Malaikat rahmah diciptakan dengan hanya tangan kanan Allah (atau dengan sifat-sifat Jamäliyyah-Nya). Sedangkan setan diciptakan dengan hanya tangan kiri Allah (sifat-sifat Jaläliyyah-Nya). Lihat Murata, The Tao..., 33). 
mempertegas kenyataan bahwa manusia dan alam semesta secara bersama-sama mempresentasikan Sang Pencipta. ${ }^{?}$

Orang-orang bijak generasi pertama melihat bahwa dunia fisik ini dengan pandangan mata mereka dan menyaksikan dimensi-dimensi segala sesuatu yang tampak dengan persepsi indera mereka. Kemudian mereka merenungkan keadaankeadaan kosmos dengan akal mereka, mengkaji dengan cermat lingkup aktivitas individu-individu universalnya dan mengetahui berbagai ragam dari segala sesuatu yang bersifat individual dalam kosmos. Mereka tak menemukan satu bagian pun dari kosmos yang lebih lengkap dalam struktur, lebih sempurna dalam bentuk, dan lebih serupa dalam totalitas ketimbang manusia.

Manusia yang lahir dari jasad, sekaligus dari tubuh ragawi dan jiwa spiritual. Karena itu, orang-orang bijak itu menemukan keserupaan bagi segala sesuatu yang ada di dunia materi dalam kondisi struktur tubuhnya. Dalam hal ini, Nasafi menunjukkan tujuh benda langit yang memiliki keserupaan dengan organorgan tubuh manusia. Bagi Nasafi, paru-paru adalah langit pertama yang menujukkan wilayah bulan, karena bulan adalah paru-paru makro kosmos. Otak sebagai langit kedua yang melambangkan wilayah Merkurius, karena Merkurius adalah otak makro kosmos. Ginjal adalah langit ketiga dan melambangkan wilayah venus, karena Venus adalah ginjal makro kosmos. Jantung adalah langit keempat dan melambangkan wilayah matahari, karena matahari adalah jantung makro kosmos. Limpa adalah langit kelima dan melambangkan wilayah Mars, karena Mars adalah limpa makro kosmos. Hati adalah langit keenam dan melambangkan wilayah Yupiter, karena Yupiter adalah hati makro kosmos. Kantong empedu adalah langit ketujuh dan melambangkan wilayah Saturnus, sebab Saturnus adalah kantong empedu makro kosmos. ${ }^{10}$

'Diadaptasi dari Murata, The Tao..., 53-3.

${ }^{10}$ Secara simbolik dengan penjelasan ini, al-Kindi (w. $873 \mathrm{M}$ ) membuat teoretisasi bahwa jiwa manusia yang masih kotor harus menyucikan diri terlebih dahulu ke bulan. Setelah jiwa tersucikan di bulan, selanjutnya jiwa beranjak ke Merkuri, dan terus meningkat sampai ke Alam Akal. Lihat, Harun Nasution, Falsafat dan Mistisime dalam Islam (Jakarta: Bulan Bintang, 1999), 12. 
Penjelasan benda-benda langit tersebut sebagai padanan organ-organ tubuh manusia tersebut di atas, merupakan korespondensi dan analogi tujuh organ manusia. Tujuh benda langit yang menempati wilayah tertentu, berkorespondensi dengan tujuh wilayah Malakuti kosmos yang di masing-masing dihuni oleh sekelompok Malaikat yang dipimpin oleh Malaikat dengan nama-nama, seperti yang dikenal dengan Malaikat sepuluh, seperti Jibril di wilayah Merkurius (langit kedua), Israfil di wilayah Matahari (langit keempat), Mikail di wilayah Jupiter (langit keenam), dan Izra'il di wilayah Saturnus (langit ketujuh). Analogi-analogi seperti ini juga dijumpai pada banyak kosmolog Muslim lainnya, seperti Ibn 'Arabī dan para pengikutnya, 'Abd al-Raḥmān Jami’, 'Abd al-Razāq al-Kasyani, dan Najm al-Dīn Rāzī.

\section{Fitrah Manusia: Dimensi dan Potensi}

Dalam bahasa Arab, fitrah mempunyai arti belahan, muncul, kejadian dan penciptaan. Jika dihubungkan dengan manusia, fitrah adalah apa yang menjadi kejadian atau bawaannya sejak lahir atau keadaan semula jadi. ${ }^{11}$ Al-Isfahānī, ketika menjelaskan makna fitrah dari segi bahasa, dia mengungkap kalimat, "fathara al-Läh al-khalq", yang maksudnya Allah mewujudkan sesuatu dan menciptakan bentuk kemampuan untuk melakukan perbuatanperbuatan. $^{12}$

Dalam al-Qur'an, kata fitrah dengan berbagai bentuk kejadiannya disebut 28 kali, 14 kali disebut dalam konteks pembicaraan tentang manusia, baik tentang fitrah penciptaan maupun fitrah keagamaan (Qs. 30: 30). Dengan demikian, makna fitrah adalah suatu kekuatan (potensi terpendam) yang menetap pada diri manusia sejak awal kejadiannya guna komitmen terhadap nilai-nilai keimanan, cenderung kepada kebenaran (hanif). Mereka tidak dapat menghindar meskipun boleh jadi mengabaikan fitahnya sendiri. Para pemikir muslim cenderung memaknai fitrah sebagai potensi manusia untuk

${ }^{11}$ Lihat, Ibn Manzhur, Lisān al-'Arab (t.tp: Dār al-Ma'ārif, t.t.), 3432-5.

${ }^{12}$ Al-Ragib al-Ișfahānī, Al-Mufradāt fì Garb al-Qur'ān (Beirut: Dār alMa'ārif, t.t.), 396. 
beragama (Tawhid ilà al-Läh), ${ }^{13}$ tetapi ada juga yang memaknai fitrah sebagai iman bawaan yang telah diberikan Allah sejak manusia berada dalam alam rahim. ${ }^{14}$ Pendapat ini merujuk pada al-Qur'an Surah al-A'raf (7): 172. Sementara Ibn Taimiyah menyebutkan tiga potensi fitrah manusia lainnya, yaitu: Pertama, daya intelektual (qumwat al-'aq), yaitu potensi dasar yang memungkinkan manusia dapat membedakan nilai baik dan buruk. Kedua, daya ofensif (quwwat al-shahwah), yaitu potensi dasar yang dimiliki manusia yang mampu menginduksi obyekobyek yang menyenangkan dan bermanfaat bagi kehidupannya, baik secara jasmaniah maupun rohaniah. Ketiga, daya defensif (quwwat al-gadbah), yaitu potensi dasar yang dapat menghindarkan manusia dari segala perbuatan yang membahayakan dirinya. Ketiga potensi tersebut, potensi akal menempati posisi sentral sebagai alat kendali dua potensi lainnya. ${ }^{15}$

Sebagaimana yang dikutip Madjid, Ibn Taimiyah membagi fitrah manusia itu kepada dua bentuk, yaitu sebagai fitrah algarizah dan fitrah al-munazzalah. ${ }^{16}$ Fitrah al-Garizah merupakan potensi dalam diri manusia yang dibawanya sejak lahir. Bentuk fitrah ini, antara lain adalah nafs, akal, dan hati nurani. Fitrah ini dapat dikembangkan oleh manusia melalui jalan pendidikan. Sedangkan fitrah al-munazzalah merupakan potensi luar manusia. Adapun wujud fitrah ini adalah wahyu Ilahi yang diturunkan Allah untuk membimbing dan mengarahkan fitrah al-garizah berkembang sesuai dengan fitrahnya yang banif.

Dimensi-dimensi fitrah yang dimaksudkan adalah aspekaspek yang terdapat pada fitrah manusia. Khayr al-Dīn al-Zarkali berpendapat, studi tentang hakekat manusia dapat ditempuh melalui tiga pendekatan yakni (1) kondisi jasad (fisik); (2) kondisi jiwa (psikis); dan (3) kondisi keduanya (psikopisik). ${ }^{17}$ Ketiga

${ }^{13} \mathrm{Al}$-Thabathabā'i Abu al-Hujjāj Mujāhid bin Jabar al-Makhzūmī, Tafsìr Mujāhid (Beirut: Al-Mansūrah al-'Ilmiyyah, 1983), 329.

${ }^{14}$ Ibn Manzur, Lisān al-'Arab..., 56

15Dikutip dari Nurcholish Madjid dalam Madjid, Kebebasan Rubani dan Cinta Ilabi: Sudut Pandang Interpretasi Sufi. Makalah KKA Paramadina, 15 September 2000, 7.

16Ibid., 8.

${ }^{17}$ Muḥammad 'Abd al-'Aẓim Al-Zarqānī, Manabil al-'Irfān fì Ulūm alQur'ān (Beirut: Dār al-Fikr, 1999), 36. 
kondisi tersebut dalam terminologi Islam, lebih dikenal dengan terma al-jasad, al-rüh, dan al-nafs. Di samping ketiga istilah tersebut, ada terma-terma lain seperti al-qalb, al-'aql, al-shabwah.

Dari pengamatan sepintas, tampak bahwa manusia menujukkan karakteristik yang sangat unik. Berbeda dalam berbagai dimensi, aspek, struktur, hal, sifat, dan aktivitasnya. Pada saat yang sama, manusia dalam berbagai eksistensinya memiliki keserupaan-keserupaan dengan ciptaan lainnya di alam semesta. Berdasarkan kenyataan ini, dan kenyataan-kenyataan tersembunyi lainnya, kosmolog Muslim menyebut manusia sebagai mikro kosmos untuk membedakannya dengan makro kosmos. Pada umumnya, orang memahami bahwa mereka menjadi bagian alam semesta, atau yang selain-Nya. Ibn 'Arabī, misalnya menyimpulkan bahwa manusia adalah makhluk serba mencakup untuk merujuk kepada manusia sempurna (al-Insān alKämi), yakni mencakup al-Haqqiyah dan al-Khalqiyyah. ${ }^{18}$

Dalam analisis kosmolog Muslim membuktikan keunikan manusia, sebagaimana diungkapkan oleh Sachiko Murata sebagai berikut:

Ada dua perbedaan mendasar antara manusia dan makhluk lainnya. Yang pertama adalah bahwa manusia merupakan totalitas, sementara makhluk-makhluk lainnya adalah bagian dari totalitas. Manusia mamanifestasikan seluruh sifat makro kosmos, sementara makhlukmakhluk lainnya memanifestasikan sebagian sifat dengan mengesampingkan yang lainnya. Manusia diciptakan dalam citra Allah, sementara makhluk-makhluk lain hanya sebagian bentuk dan

${ }^{18}$ Untuk penjelasan pandangan Ibn Arabi ini, lihat, Su'ad al-Hakìm, $A l-$ Mu'jam al-Süfi: al-Hikmah fì Hudūd al-Kalimah (Beirut: Dār al-Nadrah, t.t.), 985-8. Di tempat lain, Mu’jam ini, Ibn Arabi menyebut realitas serba mencakup manusia ini dengan Kitab Serba mencakup (al-Kitäb al-Jämi') yang merujuk kepada Adam yang eksistensinya merangkum keragaman hakekat yang tersebar di alam semesta. Bandingkan dengan penjelasan Amatullah Armstrong, Sufi Terminology, Al-Qamus As-Sufi: The Mystical Language of Islam (Malaysia: AS Nordeen, 1995). Terjemahan Bahasa Indonesia oleh MS. Nasrullah dan Achmad Baiquni (Bandung: Mizan, 2001), 139. Dalam kamus tersebut, dijelaskan: "al-Kawn al-Jami' adalah ciptaan dan maujud serba meliputi. Manusia Paripurna adalah al-Kawn al-jami' karena dia menghimpun dalam dirinya segala sesuatu dalam Hakekat Ilahi dan segala sesuatu dalam kosmos. Dia adalah lokus manifestasi bagi Nama Serba meliputi (al-Ism Aljami', yakni Allah". 
konfigurasi kualitas-kualitas Allah. Perbedaan mendasar kedua adalah bahwa makhluk-makhluk lainnya mempunyai jalur-jalur yang pasti dan tidak pernah menyimpang darinya. Sebaliknya, manusia tidak mempunyai hakekat yang pasti karena mereka memanifestasikan keseluruhan. Keseluruhan sama sekali tidak bisa didefinisikan, karena identik dengan "bukan sesuatu", bukan kualitas atau kualitas-kualitas khusus. Karena itu, manusia bertolak belakang dengan makhlukmakhluk lainnya merupakan suatu misteri. Hakekat utama manusia tidak diketahui. ${ }^{19}$

Hakekat manusia, seperti dalam catatan Murata di atas, tidak diketahui. Ini tampaknya sejalan dengan pandangan banyak pemikir Muslim yang menyatakan bahwa hakekat manusia adalah ruhnya, sementara ruh itu sendiri diungkapkan oleh alQur'an sebagai entitas yang hanya diketahui oleh Allah. ${ }^{20}$ Demikian pula, al-Qur'an mengungkapkan bahwa faktor kesempurnaan manusia, terletak pada ruh yang dihembuskan Allah kepadanya.

Faktor-faktor kesempurnaan manusia oleh agama dijelaskan sebagai berikut: (1) kejadian manusia dalam bentuk terbaik (Ahsanu taqwim) (2) dicipta dengan kedua Tangan Allah (Khalaqtu bi yadayya), sementara makhluk lain hanya dengan perintah "Kun" (jadilah!) (3) dicipta berdasarkan bentuk atau citra Allah (shurah Allab) (4) ditiupkannya ruh Allah (Rūh al-Läh) kepadanya, serta (5) manusia merupakan puncak penciptaan dengan kesempurnaan. Semua itu telah menjadikannya makhluk yang paling refresentatif dan kualitatif mengemban tugas sebagai

${ }^{19}$ Murata, The Tao.., 71. Definisi manusia selalu simplifikasi jika ingin merangkum keseluruhanNya. Makhluk apa pun dalam kosmos tak akan mampu memahami manusia dengan berbagai misterinya. Kompleksnya manusia, bahkan sejak belum menjadi manusia sempurna ketika diciptakan, memberi ruang untuk disalahpahami. Dalam al-Qur'an, malaikat dan iblis tidak dapat memahami manusia. Lihat, Muhyiddīn ibn 'Arabī, Fuṣūs alHikam (Beirut: Dār al-Kitāb al-'Arabī, t.t.), 50-1.

${ }^{20}$ Dalam pengertian sebaliknya, bisa disimpulkan bahwa hanya manusia yang dapat memahami Allah. Ini tersimpul dari salah satu tipe pemahaman mengenai seluruh nama-nama (al-asmä) yang diajarkan Allah kepada Adam ketika proses penyempurnaan ciptaanya selesai dengan ditiupkan ruh Allah ke dalam dirinya. Salah satu tipe penafsiran dimaksud adalah bahwa keseluruhan nama-nama itu adalah keseluruhan nama-nama Allah (asma' Allab), di samping pendapat yang menyatakan bahwa nama-nama itu adalah nama-nama benda di sekitar. 
khalifah Allah (Khalifah al-Läh), mewakili Allah pada tataran makhluk. Menyandang status sebagai khalifah Allah berarti hanya manusialah yang dapat menguasai alam semesta, menjamin keharmonisan. Dalam pengertian sebaliknya, hanya manusia pulalah yang mampu mengacaukan alam semesta.

\section{Alegori Penciptaan dan Kejatuhan Adam}

Kisah-kisah penciptaan Adam dan dijadikan khalifahnya, keberatan-keberatan Malaikat dan Iblis atas keputusan Allah, pengajaran Allah kepada Adam berupa nama-nama, serta kejatuhan Adam ke bumi, dikemukakan secara gamblang terbaca dalam Qs. 2:30-39 berikut ini:

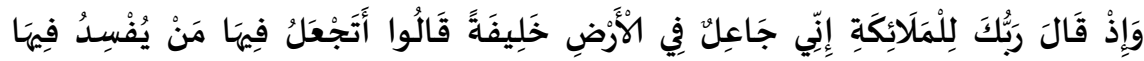

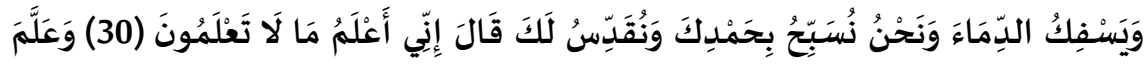

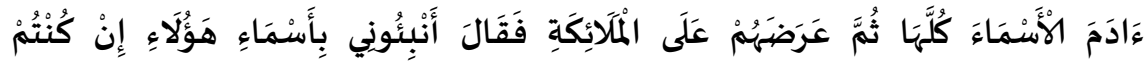

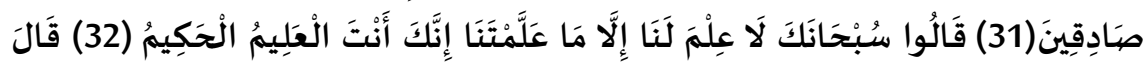

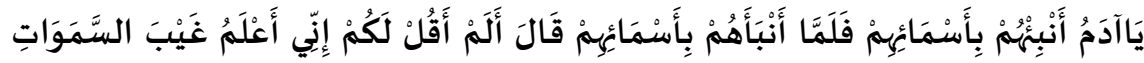

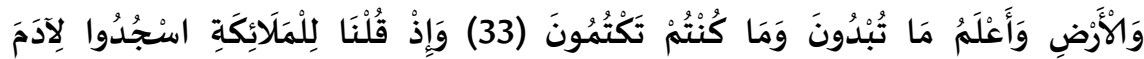

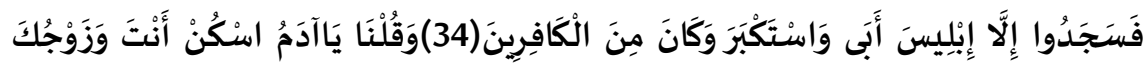

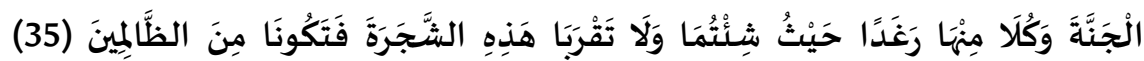

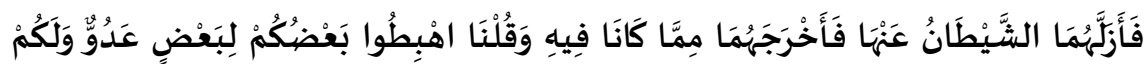

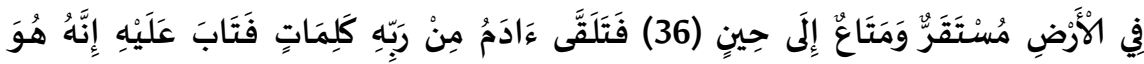

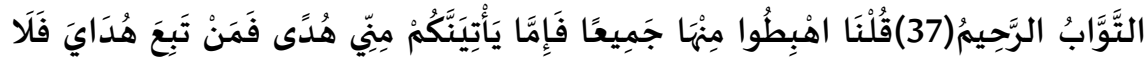

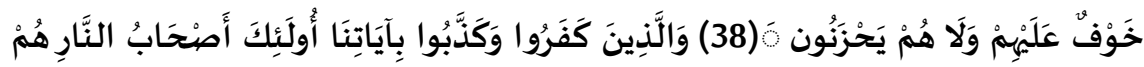

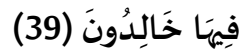

Artinya: Ingatlah ketika Tuhanmu berfirman kepada para Malaikat: "Sesunggubnya Aku hendak menjadikan seorang khalifah di muka bumi". Mereka berkata: "Mengapa Engkau hendak menjadikan (khalifah) di bumi itu orang yang akan membuat kerusakan padanya dan menumpabkan darah, padahal kami senantiasa bertasbih dengan memuji Engkau dan mensucikan Engkau?" Tuhan berfirman: "Sesunggubnya Aku mengetahui apa yang tidak kamu ketahui". Dan Dia mengajarkan kepada Adam nama-nama (benda-benda) selurubnya, kemudian mengemukakannya kepada para Malaikat lalu berfirman: "Sebutkanlab kepada-Ku nama benda-benda itu jika kamu memang orang-orang yang benar!"; Mereka menjawab: "Maha Suci Engkau, tidak ada yang kami ketabui selain dari apa yang telab Engkau ajarkan 
kepada kami; sesunggubnya Engkaulah Yang Maha Mengetabui lagi Maha Bijaksana; Allah berfirman: "Hai Adam, beritabukanlah kepada mereka nama-nama ini". Maka setelah diberitabukannya kepada mereka namanama benda itu, Allah berfirman: "Bukankah sudah Kukatakan kepadamu, bahwa sesunggubnya Aku mengetahui rahasia langit dan bumi dan mengetabui apa yang kamu nyatakan dan apa yang kamu rahasiakan?"; Dan (ingatlah) ketika Kami berfirman kepada para Malaikat: "Sujudlah kamu kepada Adam", maka mereka bersujud, kecuali Iblis; ia enggan dan takabur dan ia tergolong orang-orang yang ingkar; Dan Kami berfirman: "Hai Adam diamilah surga ini olehmu dan isterimu, dan makanlah makanan-makanannya yang banyak lagi baik di mana saja yang kamu sukai, tapi janganlah kamu dekati pohon ini, yang menyebabkan kamu termasuk orang-orang yang zalim; Lalu setan menggelincirkan keduanya dari surga itu dan dikeluarkan dari keadaan semula dan Kami berfirman: "Turunlab kamu! sebagian kamu menjadi musub bagi yang lain, dan bagi kamu ada tempat kediaman di bumi, dan kesenangan bidup sampai waktu yang ditentukan"; Kemudian Adam menerima beberapa kalimat dari Tubannya, maka Allah menerima taubatnya. Sesunggubnya Allab Maha Penerima taubat lagi Maha Penyayang; Kami berfirman: "Turunlah kamu semua dari surga itu! Kemudian jika datang petunjuk-Ku kepadamu, maka barang siapa yang mengikuti petunjuk-Ku, niscaya tidak ada kekhawatiran atas mereka, dan tidak (pula) mereka bersedib hati"; Adapun orang-orang yang kafir dan mendustakan ayat-ayat Kami, mereka itu penghuni neraka; mereka kekal di dalamnya).

Banyak ahli hikmah yang tertarik merenungkan dan mengungkap makna di balik misteri penciptaan Adam dan kejatuhannya. Perhatian mereka, bukan tertuju kepada aspek sejarah atau kisahnya, melainkan berbagai bentuk korespondensi antara manusia, kosmos, dan Allah. Salah satu hikmah yang ingin mereka ungkap adalah pengetahuan tentang keserba mencakupan manusia dibandingkan dengan ciptaan lainnya. Peran yang dapat dan harus dimainkan dalam kerangka hubungan-hubungan kosmologis. Beberapa di antara mereka yang mengungkapkan penghayatannya adalah 'Abd al-Raḥmān Jāmi', Ikhwān al-Ṣafa, dan Najm al-Dīn Rāzì.

'Abd al-Raḥmān Jāmi' menjelaskan, secara puitis dalam baitbait prosanya. Tampak bahwa Jami' ingin membuktikan bahwa karena sifat Jamäliyyah manusia, baik Malaikat maupun Iblis, tidak akan dapat memahami manusia. Malaikat maupun Iblis, kendatipun keduanya makhluk-makhluk cemerlang, namun mereka tetap tidak dapat memahami manusia, karena mereka adalah bagian, atau hanya mencerminkan satu bagian dari 
keseluruhan yang disandang manusia. Penjelasan Jami' tersebut dikutip agak panjang oleh Sachiko Murata berikut ini: ${ }^{21}$

Para Malaikat tidak kuasa memahami makna ini. Karena itu, mereka melonggarkan lidah kritik atas Adam dan memberi kesaksian bahwa dia (Adam) akan "berbuat kerusakan dan menumpahkan darah" (Qs. 2:30). Adalah di lular jangkauan para Malaikat untuk memahami kelembutan ini. Kala Adam diberi jibah kehormatan-Nya, mereka harus berbicara dengan arogansi dan pretensi. "Ya Allah, kami senantiasa bertasybih memuji-Mu, kami melantunkan pujian kepada-Mu, kami membereskan segala sesuatu. Mengapa engkau mengaduk sebuah bentuk dari air dan tanah, orang yang akan berbuat kerusakan dan menumpahkan banyak darah?”

Penjelasan Najm al-Dīn Rāzì di bawah ini tampaknya menarik untuk dicermati. Adanya dua busur yang sangat penting dalam memahami mengapa Adam mengalami kejatuhan. Kedua busur itu adalah Busur Menurun dan Busur Meningkat yang terentang dari asal-usul (Mabda) dan tujuan akhir atau tempat kembali (Ma'ad). Dua busur itu, baik dalam makro kosmos maupun mikro kosmos, terjadi proses menurun dan proses meningkat dalam pengertian yang luas. Penurunan berarti menjauh dari dunia ruh yang mewakili kesederhanaan dan memasuki dunia materi atau dunia jasmani yang mencerminkan kemajemukan. Dunia ruh dengan demikian, merupakan tataran atas (baca: tinggi). Sementara dunia materi adalah dunia yang di bawah (baca: rendah). Di bawah ini, penulis kutipkan ulasan Rāzī berkenaan dengan penciptaan Adam dan kejatuhannya:

Allah berfiman: "Sesunggubnya Aku menciptakan manusi dari tanah" (Qs. 38:71). Nabi bersabda, seraya mengutip firman Allah "Aku mengolah tanah Adam dengan kedua tangan-Ku sendiri selama empat puluh hari'" ${ }^{22}$ Hendaknya engkau ketahui bahwa manakala dikehendaki untuk

${ }^{21}$ Murata, The Tao..., 63-4, kutipan dari Abdurrahmmān Jāmi', Silsilat ..., 66-9.

${ }^{22}$ Sachiko Murata memberi catatan tentang hadis ini. Hadis ini sering dikutip dalam sumber-sumber Sufi, tapi tidak dijumpai dalam berbagai koleksi hadis standar. Hadis ini disinggung juga oleh Willian C. Chittick "Mitos Turunnya Adam dalam Rawh al-Arwah Aḥmad Sam'ani", dalam Seyyed Hossein Nasr, et.al., The Heritage of Sufism: Calassical Persian Sufism from its Origin to Rumi, Edisi Bahasa Indonesia oleh Gafna Raizha Wahyudi (Jakarta: Pustaka Sufi, 2002), 401-26. Chittick memberi catatan bahwa perhatian Tuhan untuk membuat makhluk tunggal ini cukup besar, karena 
membentuk kerangka manusia dari empat unsure (air, api, udara, dan tanah) kesemuanya tidak tersimpan dalam sifat kesederhanaan (basit, simple). Sebaliknya, semuanya itu diturunkan melalui derajat menurun. Derajat turun pertama adalah derajat kemajemukan (murakkabat, muliplicity), sebab unsur pada tahap kesederhanaan itu lebih dekat kepada dunia ruh (al-'Alam al-Rühāñ), seperti telah kami jelaskan. Ketika dikehendaki untuk membawa unsur itu kepada kedudukan kemajumukan, maka ia mesti meninggalkan kesederhanaan dan bergerak menuju kemajemukan. Karena itu, ia turun satu derajat lagi menjauhi dunia ruh. Manakala ia tiba pada kedudukan nabati, maka ia harus melewati kedudukan kemajemukan dan keadaan mati. Karena itu, ia turun satu derajat menjauhi dunia ruh. Manakala ia sudah meninggalkan wilayah nabati untuk memasuki wilayah hewani, maka ia turun satu derajat lagi. Tidak ada derajat yang lebih rendah dari manusia. Inilah yang disebut "yang paling rendah dari yang rendah" (Asfala sāfilìn, dalam Qs. Al-Tìn: 3-4)”.23

Dari kutipan di atas, Rāzi ingin mengatakan bahwa proses penurunan terjadi ketika menjauh dari Yang Esa menuju kemajemukan duniawi. Berdasarkan makna ini, maka kejatuhan Adam berarti menjauhnya Adam dari Allah, ketika ia melakukan kesalahan, yakni berbuat sesuatu yang dilarang oleh-Nya. Selanjutnya, alegori ini akan berarti setiap tindakan melanggar aturan Allah akan membuat seseorang secara bertahap menurun dalam arti menjauh dari Allah. Kemenjauhan ini dimungkinkan salah satunya oleh sifat totalitas manusia, sekaligus adanya dualitas polar di dalam dirinya. Dua busur menurun dan menaik ada dalam diri manusia. Dalam catatan di atas, penurunan kemanusiaan melalui proses menjauh untuk memasuki dunia di bawah manusia yaitu dunia hewan sampai ke dunia materi atau benda mati. Sebaliknya, proses meningkatkan kemanusiaan berlangsung melalui busur menaik, dalam pengertian naik dari dunia materi kepada dunia hewani, lalu ke dunia ruhani. Rāzì selanjutnya mengungkapkan bahwa yang tertinggi dari yang

ketika menciptakan segala yang lain, termasuk langit dan bumi, Tuhan hanya berkata, "Jadilah", dan jadilah Dia. Sam'ani mengingatkan bahwa menurut al-Qur'an, satu hari di sisi Tuhan sama dengan seribu tahun kita (Qs. 22: 47). Jadi, empatpuluh hari yang diperuntukkan kepada Adam adalah periode waktu yang sangat panjang.

${ }^{23}$ Diadaptasi dari Murata, The Tao..., 66-7. 
tinggi adalah ruh manusia, sembari menyebutkan sebaliknya, yakni yang terendah dari yang rendah adalah raga manusia.

Kata-kata ini berkaitan dengan unsur-unsur yang turun melewati derajat-derajat menurun yang menandai jauhnya dari ruh-ruh. Tetapi, jika Anda melihat Alam Malakut dari bendabenda mati, sesudah melewati beberapa tataran, akhirnya sampai pada tataran manusia. Karenanya ini menyangkut derajat yang menaik, dan bukan derajat yang menurun. Pada setiap kedudukan, Alam Malakut bergerak mendekati ruh-ruh itu, dan tidak menjauhinya. Namun, kita sedang berbicara tentang format lahiriah unsur-unsur itu, yang disebut Kerajaan (al-'Alam alMulk), dan bukan Alam Malakut dari unsur-unsur itu. Dengan demikian, jelaslah bahwa derajat tertinggi dari yang tinggi adalah ruh manusia, sementara yang terendah dari yang rendah adalah raga manusia. ${ }^{24}$

Karena ruh manusia berkaitan dengan derajat tertinggi dari yang tinggi, maka tidak ada sesuatu pun di dunia ruh yang bisa menyamai kekuatannya, termasuk malaikat, setan. Demikian pula, jiwa (al-Nafs) manusia berkaitan dengan derajat yang paling rendah dari yang rendah, sehingga tak ada sesuatu pun di dunia jiwa bisa mempunyai kekuatan, entah itu hewan dan binatang buas atau lainnya.

Ketika mengaduk dan mengolah tanah Adam, semua sifat Setan, hewan dan binatang buas, tumbuh-tumbuhan, dan bendabenda mati diaktualisasikan. Hanya saja, tanah itu dipilih untuk mengejawantahkan sifat "dua tangan-Ku". Karenanya, masingmasing sifat tercela ini, hanya sekedar kulit luar. Dalam setiap sifat, ada mutiara dan permata berupa sebuah sifat Ilahi. Anda

\footnotetext{
${ }^{24}$ Syaikh Majduddin Bagdadi mengatakan dalam kumpulan karyanya: "Segala puji bagi Dia yang menyatukan segala yang terdekat dari yang dekat dengan yang terjauh dari yang jauh melalui kekuasaanNya" Raga manusia termasuk ke dalam derajat terendah, sementara ruh manusia termasuk ke dalam derajat tertinggi. Hikmah yang ada dalam hal ini ialah bahwa manusia mesti mengemban beban Amanat Allah. Karena itu, mereka harus mempunyai kekuatan dalam kedua dunia ini untuk mencapai kesempurnaan (al-Kamāl). Sebab, tak ada sesuatu pun di kedua dunia ini yang memiliki kekuatan yang mampu mengemban beban Amanat. Mereka mempunyai kekuatan ini melalui esensi sifat-sifatnya (sifat-sifat ruhnya), bukan melalui raganya.
} 
tahu bahwa sinar matahari mengubah batu granit menjadi kerang yang mengandung permata, akik, merah delima, zamrud, dan pirus.

Adam dipilih karena "Aku mengaduk dan mengolah tanah Adam dengan kedua tangan-Ku" selama empat puluh hari. Menurut sebuah hadis, masing-masing hari itu sama dengan seribu tahun. Maka, perhatikanlah, untuk permata yang mana tanah Adam menjadi kulit kerangka? Dan Adam dimuliakan, seperti ini sebelum ruh ditiupkan ke dalam dirinya. Inilah peruntungan bagi kerangka tubuh, yang akan menjadi istana khalifah Allah. Selama empatpuluh ribu tahun, Dia bekerja dengan status-Nya sebagai Tuhan. Siapa yang tahu khazanahkhazanah apa yang disiapkannya di sana?25

Salah satu analisis tentang penciptaan dan kejatuhan Adam yang cukup menarik adalah dengan mengaitkan penciptaan dengan cinta dan kejatuhan dengan kekerasan Allah. Analisis ini diungkapkan oleh Aḥmad Sam'ānī dalam kitab Rawh al-Arwāḥ sebagai berikut:

Tuhan menciptakan setiap makhluk sesuai dengan tuntutan kekuasaan, tatapi Dia menciptakan Adam dan anak keturunannya sesuai dengan tuntutan cinta. Dia menciptakan makhluk lain berkaitan dalam kemenjadiannya yang Maha Kuat, tetapi Dia menciptakan kamu dalam kaitannya menjadi Sahabat. Adam masih seorang anak kecil, sehingga Tuhan membawanya ke jalan perawatan. Jalan anak-anak adalah satu hal, tungku perapian para pahlawan adalah hal lain. Adam kemudian dimasukkan ke Surga di pundak para Malaikat besar dari kerajaan Tuhan. Surga dijadikan ayunan untuk kebesarannya dan bantal bagi kepemimpinannya, karena dia masih belum mampu menumpu tahta kekerasan. Tuhan membawa Adam masuk ke taman kelembutan dan mendudukkannya di atas singgasana kebahagiaan. Dia memberinya guci keriangan, satu demi satu. Kemudian Dia mengeluarkannya, membuatnya berduka, membakar, membuatnya meratap Sehingga, sebagaimana Tuhan membiarkan dia mencicipi guci kelembutan pada awalnya, maka juga membuatnya merasakan tegukan kekerasan yang murni, tidak tercampur, dan tanpa penyebab. ${ }^{26}$

Ulasan Sam'ani di atas, menjelaskan bahwa dengan penciptaan Adam, nama-nama dan sifat Jamäliyyah Allah

25Diadaptasi dari Murata, The Tao..., 67-8.

${ }^{26}$ Chittick, Mitos ..., 408-11. 
teraktualisasi, sementara terusirnya Adam dari Surga adalah aktualisasi sifat-sifat dan nama-nama Jaläliyyahnya. Dalam sebuah penuturannya, Sam'ani menyatakan, Para Malaikat dihormati oleh Kehadiran Ilahi. Masing-masing mereka menyembah sambil mengenakan jubah, tanpa dosa dan subang kepatuhan. Tetapi, segera setelah giliran bumi tiba, mereka keluar dari puncak kesucian mereka dan menyombongkan diri 'Aku, dan tak ada yang lain.' Mereka berkata, 'Kami senantiasa bertasybih memujiMu" (Qs. 2:30). "Wahai Malaikat langit, Meskipun kalian patuh, kalian tidak memiliki hasrat buta dalam jiwamu, tidak pula kalian memiliki kegelapan dalam tubuhmu. Jika manusia durhaka, mereka memiliki hasrat buta dan kegelapan. Kepaatuhan kalian bersama seluruh kekuatan kalian tidaklah berharga setitik debu di hadapan keagungan dan kebesaranKu. Kedurhakaan mereka bersama dengan perpisahan dan kepatahhatian mereka tidak melenyapkan ranahKu. Melalui kepatuhan kalian, kalian mewujudkan kesucian dan kebesaran kalian sendiri; tetapi, melalui kedurhakaan mereka, mereka mewujudkan karunia dan kasih-Ku", ${ }^{27}$

\section{Membangun Spritualitas Manusia}

Struktur kepribadian manusia terungkap dalam berbagai fakultas spiritual. Fakultas-fakultas spiritual tersebut oleh para pencari kebenaran melakukan aktivitasnya, baik dalam pengertian melakukan pendakian spiritual atau pun dalam meningkatkan fakultas-fakultas spiritual itu sendiri. Mereka tertarik dengan sebuah hadis Nabi yang sangat terkenal dalam kalangan tradisi sufistik: "Barangsiapa yang mengenal dirinya, maka ia mengenal Tubannya". Mereka berupaya menemukan asosiasiasoiasi yang mungkin dalam keterkaitan manusia dengan Tuhan dan dengan alam semesta (kosmos), dengan maksud untuk memperoleh pemahaman yang lebih baik tentang tiga realitas, yakni Tuhan sebagai meta kosmos, alam semesta sebagai makro kosmos, dan manusia sebagai mikro kosmos.

Sebagaimana ditunjukkan al-Qur'an, bahwa Allah akan menunjukkan kepada manusia tanda-tandaNya di segenap

${ }^{27}$ Ibid., 421. 
cakrawala, dan dalam diri manusia sendiri, maka itu berarti tanda-tanda Tuhan dapat ditemukan dalam kedua realitas, kosmos dan manusia. Oleh karena itu, para pemikir muslim mendekatkan diri kepada Allah dengan terlebih dahulu atau secara simultan merenungkan tanda-tanda Allah dalam diri manusia dan dalam alam semesta.

Jika dalam perspektif kosmologi spiritual, kosmos dibedakan dalam dua tataran, yaitu kosmos spiritual (alam ruhani) dan kosmos fisikal (alam materi). Dalam dunia manusia (mikro kosmos), terdapat pula padanannya, yaitu dua unsur kepribadian manusia, yaitu jiwa (ruhani) dan badannya. Ruhani manusia membentuk hubungan keserasian dengan bagian alam spiritual dari kosmos, dan badan manusia membentuk hubungan keserasian dengan alam fisik kosmos. Lebih dari itu, asosiasiasosiasi yang dapat dibuat dalam hubungan dengan realitasrealitas itu, jauh lebih rumit dan mencakup semuanya, misalnya keserasian antara format fisik manusia dengan format ruhaminya. Dengan demikian, sifat-sifat dan karakteristik alam spiritual selaras dengan alam materi, dan dunia jiwa manusia. ${ }^{28}$ Hubungan-hubungan ini, tentunya akan dengan sendirinya selaras dengan Tuhan, sebagaimana diungkapkan dalam alQur'an bahwa Dialah yang Zähir dan Bätin. Keselarasan ini menyiratkan adanya keteraturan di mana saja, dan itulah rancangan besar Allah, yang mau tidak mau harus dapat disimpulkan memiliki signifikansi yang luar biasa bagi kehidupan manusia. Allah menciptakan alam semesta dan kemudian menyempurnakannya, boleh jadi penyempurnaan itu berkaitan dengan penciptaan manusia yang memiliki kualitas-kualitas Ilahiah dan kosmologis secara menyeluruh (Jam'iyyah). Sachiko Murata menyimpulkan dengan "Karena sentralitas dan sifat serba menyeluruh (Jam'iyyah) situasi manusia, maka hanya

${ }^{28}$ Dari keserasian ini memungkinkan dilakukannya berbagai bentuk analogi dalam al-Qur'an, yang mengandung pengertian sebagai pelajaran dan bahan renungan bagi manusia. Berbagai bentuk analogi dalam al-Qur'an, yang membentuk hubungan dengan alam manusia (mikro kosmos) menjadi dasar pandangan ruhani Yusuf Ali. Dia sedemikian rupa menafsirkan bahwa sebagian besar nama-nama dan peristiwa alamiah berhubungan dengan nama-nama dan peristiwa dalam jiwa manusia. Ini sudah disebutkan pada bahasan sebelumnya di atas. 
manusia sajalah yang bisa mengacaukan harmoni atau keselarasan dan keseimbangan yang secara natural terjalin antara Allah dan kosmos. Lagi pula, disebabkan oleh situasi perantara yang mereka miliki, kenyataan bahwa mereka adalah wakil-wakil Allah, maka hanya manusia sajalah yang bisa menjalin harmoni dan keseimbangan yang sempurna antara Allah dan ciptaan (makhluk). ${ }^{29}$

Konsekuensi dari kesimpulan penalaran ini, ada keharusan manusia untuk mempertahankan keselarasan dalam hubunganhubungan kosmologis. Di mana mereka menjalankan peran sentralnya. Keselarasan yang pertama kali harus diupayakan adalah keselarasan dalam diri manusia sendiri, yang mencakup keselarasan dalam struktur ruhaninya yang menjadi lokus dari segala upayanya. Keselarasan dan keseimbangan ruhani diperlukan, sekurang-kurangnya untuk mewujudkan superioritas ruhani manusia atas badan. Maka, dengan sendirinya akan bermakna kekuatan jiwa akan dapat mengendalikan gerakan badan. Jika dikaitkan dengan bentuk-bentuk hubungan analogis dalam kosmos, baik yang berlaku dalam dunia fisik maupun dalam dunia ruhani, berupa hubungan atas-bawah atau hubungan aktif-reseptif, maka dalam diri manusia terdapat bentuk-bentuk hubungan seperti itu. Hubungan ini dapat, misalnya, disimpulkan dari sebuah hadis Nabi yang menyebutkan adanya segumpal daging yang disebut jantung yang keberadaannya begitu berpengaruh kepada kualitas-kualitas fisik. Jika sehat, maka akan sehatlah seluruh anggota badan, dan sebaliknya. Dalam dunia ruhani atau dunia jiwa manusia, keadaan ini pun terjadi, di mana hati dipandang sebagai pusat acuan aktivitas ruhani, yang posisinya sama dengan esensialnya jantung bagi tubuh.

Fakultas-fakultas spiritual mencakup ruh, akal, hati, jiwa, dan hawa nafsu. Deskripsi ini sedikit berbeda, jika dibandingkan dengan pandangan para filsuf Muslim pada umumnya, seperti alKindi, al-Farābī, dan Ibn Sīnā. Al-Kindi, misalnya, menyebutkan tiga daya jiwa, yaitu: (1) daya syahwat/seks (al-Quwwat alShabwaniyyah) (2) daya marah/agresi (al-Quwwat al-Gadabiyyah),

${ }^{29}$ Murata, The Tao..., 39. 
dan (3) daya pikir (al-Qwwwat al-'Aqilah). Teori jiwa yang lebih rinci dalam perspektif filsafat dapat dijumpai pada pandangan alFarabi dan Ibn Sina. ${ }^{30}$

Fakultas-fakultas spiritual tersebut, biasanya dijelaskan dalam sebuah struktur, yaitu struktur spiritual, mungkin mengikuti analogi struktur kosmologi spiritual. Struktur spiritual ini, dalam pemikiran Islam dipandang memiliki keselarasan tertentu dengan struktur fisik manusia yang terdiri dari, kepala, leher, dada, perut, organ pembuangan, paha, betis, dan kaki dan seterusnya. Dalam spiritualitas manusia, yang mencerminkan sisi batin Allah, terdapat hubungan-hubungan, korespondensi-korespondensi, dan analogi-analogi kualitatif. Dengan demikian, ada hubunganhubungan atas bawah, aktif reseptif, keseluruhan bagian, kesederhanaan kemajemukan, dan lain-lain. Rumitnya struktur kepribadian manusia, baik fisik maupun ruhani, menjadikan kesimpulan-kesimpulan para pengkaji bersifat tentatif. Artinya masih menyisakan ruang bagi pandangan dan penemuan lainnya, yang mungkin lebih akurat.

Peran sentral manusia di dalam kosmos mengandung makna bahwa hanya manusialah yang paling menentukan keserasian sekaligus kekacauan kosmos. Keserasian dan kekacauan kosmos dapat terwujud setelah sebelumnya manusia menciptakan atau membangun keselarasan atau kekacauan dunia spiritual yang ada. Dunia spiritual manusia, mencakup beberapa fakultas yang menjalankan fungsi-fungsi aktif reseptif dalam aras atas bawah. Semuanya akan berjalan serasi, jika strukturnya dapat dipertahankan sesuai dengan fitrah penciptaannya.

\section{Catatan Akhir}

Hubungan-hubungan analogis dalam berbagai tataran eksistensial antara manusia dan kosmos menunjukkan bahwa manusia yang mewakili keseluruhan (totalitas, Jam'iyyah). Manusia dapat mengacaukan kosmos, di samping mampu menjamin harmoni alam semesta. Pendidikan yang baik adalah yang dapat menjalankan peran membimbing manusia untuk membantunya memahami kesempurnaan diri guna bertindak

${ }^{30}$ Lihat, Nasution, Falsafat dan Mistisime..., 20-34. Lihat juga Ahmad Daudy, Kuliah Filsafat Islam (Jakarta: Bulan Bintang, 1992), 28. 
menurut ajaran Allah. Kesempurnaan ciptaan manusia mengikuti hukum ketentuan Allah yang disebut al-Amr al-Takwini (Perintah Penciptaan). Sedangkan ketentuan Allah dalam wahyu yang mengajarkan manusia untuk menyelaraskan kesempurnaan penciptaannya disebut al-Amr al-Taklifi (Perintah Petunjuk). Dengan demikian, pendidikan agama tetap bersifat substansial. Argumen yang paling jelas bagi perlunya pendidikan agama, bahwa dengan bermodalkan kesempurnaan penciptaan, manusia seringkali menempuh jalan menyimpang yang justru merusak kesempurnaan diri, sekaligus pada saat yang sama, berarti mengacaukan keseimbangan psikologis dan kosmologis.

Sifat-sifat Jalaliyyah Allah bersifat aktif, sementara sifat-sifat jamaliyyah-Nya bersifat reseptif. Namun, terbukti sifat-sifat Jamaliyyah-Nya melampaui sifat-sitaf Jalaliyyah-Nya, seperti dalam hadis Qudsi disebutkan: "Rahmat-Ku mengalabkan murka-Ku". Menguasai alam semesta adalah aktualisasi aktivitas manusia, namun memeliharanya dengan penuh kasih sayang adalah sikap mulia yang harus diutamakan. Mengapa? Karena dengan kasih sayang, segala keutamaan kosmos akan terbentang sebagai anugerah yang menguntungkan kehidupan manusia. Dalam konteks psikologi manusia, ruh, akal, dan hatinya yang berada pada struktur atas dari spiritualitasnya, bersifat aktif dalam hubungannya dengan struktur bawah, yaitu nafs. Nafs pada saat yang sama, harus bersifat reseptif terhadap cahaya dari tataran atas spiritualitasnya, bukan sebaliknya, menjadikan kecenderugan-kecenderungan rendahnya menjadi acuan.

Dalam hubungan-hubungan aktif reseptif ini, dalam kerangka pendidikan, teraktualisasi misalnya pada perlunya kepemimpinan progresif dan aktif dalam hubungannya dengan warga, sementara warga perlu bersikap reseptif dalam hubungannya dengan pemimpin. Sikap reseptif ini penting, di samping untuk membentuk keselarasan kosmologis pada sebuah dunia.

Hubungan-hubungan atas bawah yang terdapat di dalam kosmos, termasuk dalam diri manusia, menunjukkan adanya dalam kerangka kependidikan, setiap manusia memiliki kesempatan yang sangat luas untuk meningkat ke taraf setinggitingginya, atau sebaliknya untuk menurun kepada taraf serendah- 
rendahnya. Kenyataan ạsani Taqwim menyiratkan peluang naik ke atas, sebaliknya asal kejadian dari tanahnya membuka peluang kembali ke asal kejadian sebagai makhluk mati. Dengan demikian, pendidikan haruslah menghidupkan, sekaligus meningkatkan taraf kemanusiaan. Pendidikan menentukan tercapainya al-Insān al-Kāmil yang substansinya berada pada ruhnya. Sekaligus menyiratkan jati diri yang mulia dan tinggi. Inilah yang tersimpul dalam tugas kekhalifahannya di muka bumi ini. Wa al-Läh a lam bi al-sawàb.

\section{Daftar Pustaka}

Armstrong, Amatullah. 1995. Sufi Terminology, Al-Qamus As-Sufi:

The Mystical Language of Islam. Malaysia: AS Nordeen.

Carrel, Alexis. 1987. Misteri Manusia. Bandung: Remaja Karya.

al-Hakìm, Su'ad. t.t. Al-Mu'jam al-Süfì: al-Hikmat fì Hudūd alKalimah (Beirut: Dār al-Nadrah.

Ibn 'Arabī, Muhyiddin. t.th. Fusus al-Hikam, Diedit oleh Abu al'Alā 'Āfifi (Beirut: Dār al-Kitāb al-'Arabī.

Ibn Manzhur. t.t. Lisān al-'Arab. t.tp.: Dār al-Ma'ārif.

Al-Ișfahānī, al-Ragīb. t.t. al-Mufradāt fì Garb al-Qur'àn. Beirut: Dār al-Ma'ārif.

Madjid, Nurcholish. Simbol dan Simbolisme Keagamaan Populer, serta Pemaknaannya dalam Perkembangan Sosial-Politik Nasional Kontemporer, Makalah Pidato Pengukuhan Jabatan Ahli Peneliti Utama (Jakarta: Puslitbang Kemasyarakatan dan Kebudayaan, Lembaga Ilmu Pengetahuan Indonesia 30 Agustus 1999.

al-Makhzūmī, al-Ṭabatabāà Abū al-Hujjāj Mujāhid bin Jabar. 1983. Tafsì Mujabid. Diedit oleh 'Abd Raḥmān al-Ṭāhir Muhammad al-Surati (Beirut: al-Mansurat al-'Ilmiyyah.

Murata, Sachiko. 1998. The Tao of Islam: Kitab Rujukan tentang Relasi Gender dalam Kosmologi dan Teologi Islam, ter. Rahmani Astuti dan M.S. Nasrullah. Bandung: Mizan.

Nasr, Seyyed Hossein, et.al. 2002. The Heritage of Sufism: Calassical Persian Sufism from its Origin to Rumi, Edisi Bahasa Indonesia oleh Gafna Raizha Wahyudi (Jakarta: Pustaka Sufi. 
Nasution, Harun. 1999. Falsafat dan Mistisime dalam Islam. Jakarta: Bulan Bintang.

Shihab, M. Quraish. 1998. Wawasan al-Qur'an: Tafsir Maudhu'i Atas Pelbagai Persoalan Umat. Bandung: Mizan.

Al-Zarqānī, Muḥammad 'Abd al-'Azịim. 1999. Manāhil al-Irfān fì 'Ulūm al-Qur'àn. Beirut: Dār al-Fikr. 